\title{
Seasonal Acclimatization to Temperature in Cardueline Finches
}

\section{Insulative and Metabolic Adjustments}

William R. Dawson and Cynthia Carey

Division of Biological Sciences, The University of Michigan, Ann Arbor, Michigan 48109, USA

Received April 15, 1976

Summary. 1. Seasonal variation in metabolism and insulation was measured throughout the year in American goldfinches (Spinus tristis) and during winter in pine siskins ( $S$. pinus).

2. Basal levels of metabolism of goldfinches in summer, $4.24 \mathrm{ml} \mathrm{O}_{2}(\mathrm{~g} \cdot \mathrm{h})^{-1}$, and winter, $4.65 \mathrm{ml} \mathrm{O}_{2}(\mathrm{~g} \cdot \mathrm{h})^{-1}$, do not differ significantly, but the intercept of the regression line defining the relation of oxygen consumption to ambient temperature below thermoneutrality is significantly higher for summer birds (Figs. 1, 2).

3. Basal metabolism of pine siskins, $4.52 \mathrm{ml} \mathrm{O}(\mathrm{g} \cdot \mathrm{h})^{-1}$, does not differ significantly from those of summer or winter goldfinches (Fig. 3). Basal levels for siskins and winter goldfinches were 40 and $50 \%$ higher, respectively, than values predicted by the appropriate equation of Aschoff and Pohl (1970) for passerine birds of similar size.

4. Summer goldfinches exposed to severe cold $\left(-70^{\circ} \mathrm{C}\right)$ remain homeothermic for no more than $1 \mathrm{~h}$. Winter goldfinches tolerate similar conditions for as much as 6-8 h (Fig. 5). All goldfinches tested in January remain homeothermic over at least $3 \mathrm{~h}$ below $-60^{\circ} \mathrm{C}$. None do so between April and October (Fig. 6).

5. Masses of dry contour plumage of goldfinches change from a mean of $0.57 \mathrm{~g}$ in January to $0.33 \mathrm{~g}$ in September. The changes in plumage mass are not coincident with the seasonal changes in resistance to severe cold (Fig. 7).

6. Metabolic rather than insulative adjustments appear primarily responsible for the acclimatization of American goldfinches and pine siskins to winter conditions in the northern United States.

\section{Introduction}

Small birds resident in northern areas are confronted seasonally with the interacting problems of cold, short days, and food supplies that steadily diminish 
owing to the lack of production, utilization by animals, and snow cover. Cold increases the requirements of these diurnally feeding animals for energy and materials when the daily periods in which to obtain food are most restricted. Adjustments of small passerine birds to winter conditions have attracted considerable attention over the past two decades (see summaries by West, 1962; Dawson and Hudson, 1970; Calder and King, 1974). The extent of seasonal acclimatization to cold has received some analysis. Certain of the analyses have approached the problem of acclimatization through study of metabolic changes induced by maintenance of the birds at constant cool or warm temperatures in the laboratory (Gelineo, 1955, 1964; Chaffee et al., 1963; Steen, 1958). Others have treated seasonal phenological changes, most notably in body mass and lipid content (King and Farner, 1966; Newton, 1969; Evans, 1969; Barnett, 1970; Chaplin, 1974). Still other analyses have involved determination of seasonal changes in insulative and metabolic characteristics (Dawson, 1958; Hart, 1962; Veghte, 1964; West and Hart, 1966; Barnett, 1970; West, 1972; Pohl and West, 1973; Palokangas et al., 1975). Results obtained in these studies indicate that small birds can indeed enhance their cold resistance through acclimatization. However, the mechanisms underlying this complex process are yet to be fully characterized. Comprehensive studies of the manner in which acclimatization to winter conditions is partitioned among shifts in insulation, metabolic parameters, extent of energy reserves, and capacities for mobilizing these reserves remain to be carried out.

In view of the limited understanding of acclimatization to winter cold in small birds, we initiated studies on representatives of a group of finches that is particularly well represented in boreal environments in both the New and Old Worlds, the subfamily Carduelinae. The experimental subjects we have chosen from this group are the American goldfinch (Spinus tristis) and the pine siskin (Spinus pinus). We report here those facets of our study dealing with the characterization of the insulative and metabolic components of seasonal acclimatization to cold.

\section{Materials and Methods}

\section{Experimental Animals}

Eastern American goldfinches (S. tristis tristis) were used in this study. Representatives of this subspecies breed over the eastern half of southern Canada and much of the United States east of the Rocky Mountains. A southward shift of this range is evident in winter as the result of migratory movements of certain populations, but the eastern American goldfinch is still present in such places as northeastern Minnesota, northern Michigan, southern Ontario, southwestern Quebec, central New Brunswick, and central Nova Scotia at this season (Wetmore et al., 1957). The birds used in this study were obtained near Ann Arbor, Washtenaw County, Michigan, where goldfinches are present throughout the year. They were captured by mist netting during spring, summer, and fall. A trapping station was operated during the winter. The flocks around Ann Arbor evidently contain individuals from other localities; one goldfinch was captured that had been banded one month earlier near Grand Rapids, Kent County, Michigan, approximately $220 \mathrm{~km}$ west northwest of Ann Arbor. Despite recruitment from other areas, the goldfinch flocks around Ann Arbor do appear to have some stability of membership from year to year, allowing for natural attrition. 
Two birds banded at our trapping station in December, 1973 were recaptured there again in December, 1975. One of these individuals has been seen there repeatedly from that month until the present (March, 1976).

Pine siskins (S. pinus pinus) have a wide breeding range that includes northern and central United States (including southeastern Alaska), the Taiga in Canada, and the mountains of the western United States south to the Mexican border. They winter at lower elevations in much of this range, but in some years periodically invade areas well outside of it, appearently as they follow unpredictable food resources. The siskins used in this study were part of an invasion of southern Michigan during winter 1972-73. They were obtained at the same trapping station as the goldfinches.

Birds were transferred immediately after capture to the laboratory, where they were weighed on a Mettler top-loading balance accurate to $0.01 \mathrm{~g}$. Age, sex, and degree of molt were then determined by inspection of the plumage. The amount of fat visible beneath the skin and the reproductive status, as indicated by the presence of a brood patch in females or cloacal protuberance in males, were also noted.

In the initial phases of this study, goldfinches were held outdoors in flight cages where they were subjected to natural conditions of temperature and photoperiod. Thistle seeds, mixed wild bird seed, and water or snow were provided. Subsequently, we found it preferable to use birds directly from the field in our studies. This procedure allowed us to avoid the problems of keeping the goldfinches free from coccidiosis infections to which these birds are exceptionally prone in captivity. It also resulted in our discovery that captivity tended to interfere with the winter fattening cycle and curtail the resistance of the birds to severe cold. Pine siskins were tested during the day on which they were captured.

\section{Measurements of Standard and Peak Oxygen Consumption}

The influence of temperature on standard metabolism of goldfinches and siskins during winter was determined between December and early March. Measurements of summer goldfinches were conducted between June and August. The rates of oxygen consumption $\left(\dot{\mathrm{V}}_{\mathrm{O}_{2}}\right)$ used in our analyses were obtained between $22.00 \mathrm{~h}$ and midnight on birds that had been resting approximately $6 \mathrm{~h}$ in half-gal. metabolism chambers having blackened inner surfaces with emissivities near 1.0. These chambers were a part of a metabolism system that has been described previously (Dawson and Fisher, 1969). In this case, a model G-2 Beckman paramagnetic oxygen analyzer (20-21\% or $20.45-20.95 \% \mathrm{O}_{2}$ ) that alternately sampled up to four gas streams was used. All determinations of fractional oxygen concentrations $\left(\mathrm{F}_{\mathrm{O}_{2}}\right)$ were carried out on dry, $\mathrm{CO}_{2}$-free air, so that the appropriate equation of Depocas and Hart (1957) for monitoring of upstream flow rate could be used in calculation of true $\dot{V}_{\mathrm{O}_{2}}$, independent of variations in the respiratory quotient. Flow rates of air approximating $650 \mathrm{ml} / \mathrm{min}$ were used in the measurements of standard metabolism. These were sufficient to maintain the partial pressures of $\mathrm{O}_{2}$ and $\mathrm{CO}_{2}$ in the chambers above 150 torr and below 5 torr, respectively. All volumes of $\mathrm{O}_{2}$ specified in connection with $\dot{\mathrm{V}}_{\mathrm{O}_{2}}$ in this report have been corrected to standard conditions.

Ambient temperature within the metabolism chambers was controlled by housing them in a constant temperature cabinet or freezer that had been specially modified to provide precise thermal regulation. The cabinet was used for tests between $-10^{\circ} \mathrm{C}$ and $+34^{\circ} \mathrm{C}$ and the freezer for those between $-33^{\circ} \mathrm{C}$ and $-10^{\circ} \mathrm{C}$. Temperatures could be maintained to within $0.2{ }^{\circ} \mathrm{C}$ of the desired value with this equipment, as indicated by thermocouples ( 30 gauge, copper-constantan) in the exit ports of the chambers. These thermocouples were used in conjunction with a suitably calibrated Honeywell 15 or 16 multipoint recording potentiometer.

Capacities for thermogenesis of birds under severe $\left(-70^{\circ} \mathrm{C}\right)$ cold stress were determined in goldfinches throughout the year and in pine siskins during winter. A bird captured between 08.00 and $10.00 \mathrm{~h}$ was immediately transferred to the laboratory, where it was weighed and placed in a weighted circular plexiglas chamber $25 \mathrm{~cm}$ in diameter and $20 \mathrm{~cm}$ in height. This chamber was sealed, placed in a circular container, and connected to a metabolism circuit. Sufficient chilled $\left(-10^{\circ} \mathrm{C}\right)$ ethanol was added to the container to immerse the chamber. Dry ice was then added to the alcohol to produce a temperature of approximately $-70^{\circ} \mathrm{C}$. The temperature of the air and walls of the chamber cooled from approximately $23^{\circ} \mathrm{C}$ to this level in $45-60$ min. Dry ice 
was added throughout the test to keep the chamber at $-70^{\circ} \mathrm{C}$. The bird stood on a cardboard surface while in the chamber. It received neither food nor water during the tests.

The metabolism system employed in tests at $-70^{\circ} \mathrm{C}$ contained components similar to those in the system used in studies of standard metabolism. However, in this case the air line included $4 \mathrm{~m}$ of 1/4-inch copper tubing that was immersed in the alcohol bath to ensure full cooling of the air before it entered the chamber. In addition, an F-3 Beckman paramagnetic oxygen analyzer $\left(20-21 \% \mathrm{O}_{2}\right)$ was used, rather than the $\mathrm{G}-2$ instruments specified previously. The $\mathrm{F}_{\mathrm{O}_{2}}$ of dry $\mathrm{CO}_{2}$-free excurrent air or, at 20-min intervals, dry, $\mathrm{CO}_{2}$-free incurrent air and the temperature of the thermocouples for measuring the air or wall surfaces within the chamber were recorded on a dual range Honeywell 194 recording potentiometer. Air flowing through the chamber at $1,300 \mathrm{ml} / \mathrm{min}$ during the tests maintained the partial pressures of $\mathrm{O}_{2}$ and $\mathrm{CO}_{2}$ at levels similar to those in measurements of standard metabolism. The bird was kept in the chamber as long as $\dot{\mathrm{V}}_{\mathrm{O}_{2}}$ rose or remained at a high level. If metabolic rate dropped steadily for $5 \mathrm{~min}$, the ethanol was quickly removed from the bath and the bird taken from the chamber for measurement of body mass and body temperature $\left(T_{\mathrm{b}}\right)$.

\section{Body Temperatures}

Body temperatures of small (12-17 g) birds such as goldfinches and siskins are readily influenced by activity. Moreover, thermal gradients exist in the superficial layers of the bodies of these animals, so that care must be exercised that the actual core temperature is being determined. Body temperatures were determined at the end of metabolic tests by means of a fine, polyethylene encased thermocouple used with a Honeywell 15 or 16 recording potentiometer, or of a Schultheis thermometer designed for work with small animals. These devices were inserted through the cloaca into the large intestine to a sufficient depth so that a slight withdrawal produced no measurable drop in $T_{\mathrm{b}}$. Body temperatures of birds that became active in the course of removal from the metabolism chambers were not used in the analyses reported here.

\section{Seasonal Changes in Plumage Insulation}

Studies of avian thermoregulation over the past 25 years have generally involved calculations of whole body heat transfer coefficients $(\mathrm{C})-\mathrm{C}=\left(4.8 \times \mathrm{V}_{\mathrm{O}_{2}}\right)\left(T_{\mathrm{b}}-T_{\mathrm{a}}\right)^{-1}$-for estimation of insulation. The plumage is the principal component of insulation in small birds (Drent and Stonehouse, 1971). Therefore, we have followed the direct, though tedious procedure of weighing the contour feathers of goldfinches taken throughout the year in our analysis of the extent of insulative acclimatization in this species. Plumage was obtained from pine siskins captured in January. Contour feathers on the head, neck, and body were removed from birds that had been sacrificed for other purposes. These feathers were placed in a cellulose thimble that was then sealed with a piece of porous paper tissue. The sealed thimble was placed in a drying oven at $80^{\circ} \mathrm{C}$. The thimble was removed periodically and weighed to the nearest $\mathrm{mg}$ on a Mettler H20T balance. When it had dried to constant mass, the feathers were removed and the thimble and the tissue used to seal it redried to constant mass. The difference in the two masses represents the dry mass of the contour plumage.

\section{Statistics}

Regression lines were calculated according to the least squares method. Significant differences between slopes and intercepts of regression lines were determined by analysis of covariance. Comparison of means was done with Students' t-test when variances were proven equal. When variances were unequal, significance was assessed using non-parametric tests, either a Bayseian posterior probability derived from an approximation to the Behrens-Fisher distribution (Lindley, 1965) or a Mann-Whitney U-test. 


\section{Results}

\section{Standard Oxygen Consumption}

The zone of thermal neutrality in goldfinches extends from approximately $23^{\circ} \mathrm{C}$ to at least $35^{\circ} \mathrm{C}$ in both winter and summer (Figs. 1 and 2) and the mean rate of standard oxygen consumption $\left(\dot{\mathrm{V}}_{\mathrm{O}_{2}}\right)$ in this interval has been taken as the basal metabolic rate (BMR). This rate in summer is $4.24 \pm 0.61$ (SD) $\mathrm{ml}$ $\mathrm{O}_{2}(\mathrm{~g} \cdot \mathrm{h})^{-1}$ for $18 \mathrm{birds}$ (mean body mass $12.8 \pm 0.8$ (SD) g). It is $4.67 \pm 0.22(\mathrm{SD}) \mathrm{ml} \mathrm{O}_{2}(\mathrm{~g} \cdot \mathrm{h})^{-1}$ and $4.63 \pm 0.40$ for 6 goldfinches maintained in an outdoor flight cage in winter and for 10 others taken directly from nature at this season, respectively. These winter values do not differ significantly from one another and the data for the two groups have been combined, yielding an overall mean of $4.65 \pm 0.34(\mathrm{SD}) \mathrm{ml} \mathrm{O}_{2}(\mathrm{~g} \cdot \mathrm{h})^{-1}$ for 16 winter birds. The mean body mass of the birds in the combined sample is $14.5 \pm 1.2$ (SD) g. Their BMR does not differ significantly from that for the summer birds $(P>0.05)$.

The zone of thermal neutrality in pine siskins in winter extends from approximately $15{ }^{\circ} \mathrm{C}$ to at least $35^{\circ} \mathrm{C}$ (Fig. 3). Again, the $\dot{\mathrm{V}}_{\mathrm{O}_{2}}$ in this interval was taken as the BMR. This mean value, $4.52 \pm 0.60$ (SD) $\mathrm{ml} \mathrm{O}_{2}(\mathrm{~g} \cdot \mathrm{h})^{-1}$ for $17 \mathrm{birds}$ (mean body mass $13.8 \pm 1.5 \mathrm{~g}$ ) does not differ significantly from the comparable values for summer and winter goldfinches.

The relation of $\dot{\mathrm{V}}_{\mathrm{O}_{2}}$ to $T_{\mathrm{a}}$ from the lower boundary of thermal neutrality, $23{ }^{\circ} \mathrm{C}$, to $-35^{\circ} \mathrm{C}$ is best described in goldfinches by the following equations:

(for summer birds)

$$
\dot{\mathrm{V}}_{\mathrm{O}_{2}}=8.37-0.17 T_{\mathrm{a}}
$$

$\left(\mathrm{n}=29, \mathrm{r}=0.98, \mathrm{~S}_{\mathrm{b}}=0.007, \mathrm{~S}_{\mathrm{y} \cdot \mathrm{x}}=0.72\right)$

(for freshly captured birds in winter)

$$
\dot{\mathrm{V}}_{\mathrm{O}_{2}}=7.77-0.16 T_{\mathrm{a}}
$$

$\left(\mathrm{n}=49, \mathrm{r}=0.98, \mathrm{~S}_{\mathrm{b}}=0.005, \mathrm{~S}_{\mathrm{y} \cdot \mathrm{x}}=0.69\right)$

(for birds maintained in outdoor flight cages in winter)

$$
\dot{\mathrm{V}}_{\mathrm{O}_{2}}=7.55-0.14 T_{\mathrm{a}}
$$

$$
\left(\mathrm{n}=18, \mathrm{r}=0.79, \mathrm{~S}_{\mathrm{b}}=0.003, \mathrm{~S}_{\mathrm{y} \cdot \mathrm{x}}=0.57\right)
$$

where $\dot{\mathrm{V}}_{\mathrm{O}_{2}}$ is in $\mathrm{ml} \mathrm{O}_{2}(\mathrm{~g} \cdot \mathrm{h})^{-1}$ and $T_{\mathrm{a}}$ is in degrees Celsius. The equations for the two groups of winter goldfinches do not differ significantly and may thus be pooled into the equation:

(all winter birds)

$$
\dot{\mathrm{V}}_{\mathrm{O}_{2}}=7.73-0.16 T_{\mathrm{a}}
$$

$$
\left(\mathrm{n}=67, \mathrm{r}=0.97, \mathrm{~S}_{\mathrm{b}}=0.005, \mathrm{~S}_{\mathrm{y} \cdot \mathrm{x}}=0.61\right)
$$

Analysis of covariance of the data for summer goldfinches and the pooled data for wild and caged winter goldfinches establishes that the intercepts of Equations (1) and (4) are significantly different $(P<0.001)$, but that the slopes are statistically indistinguishable. None of these equations indicates a conformance of the particular experimental population to the so-called Newtonian model for thermoregulation in the cold; all of the regression lines extrapolate 


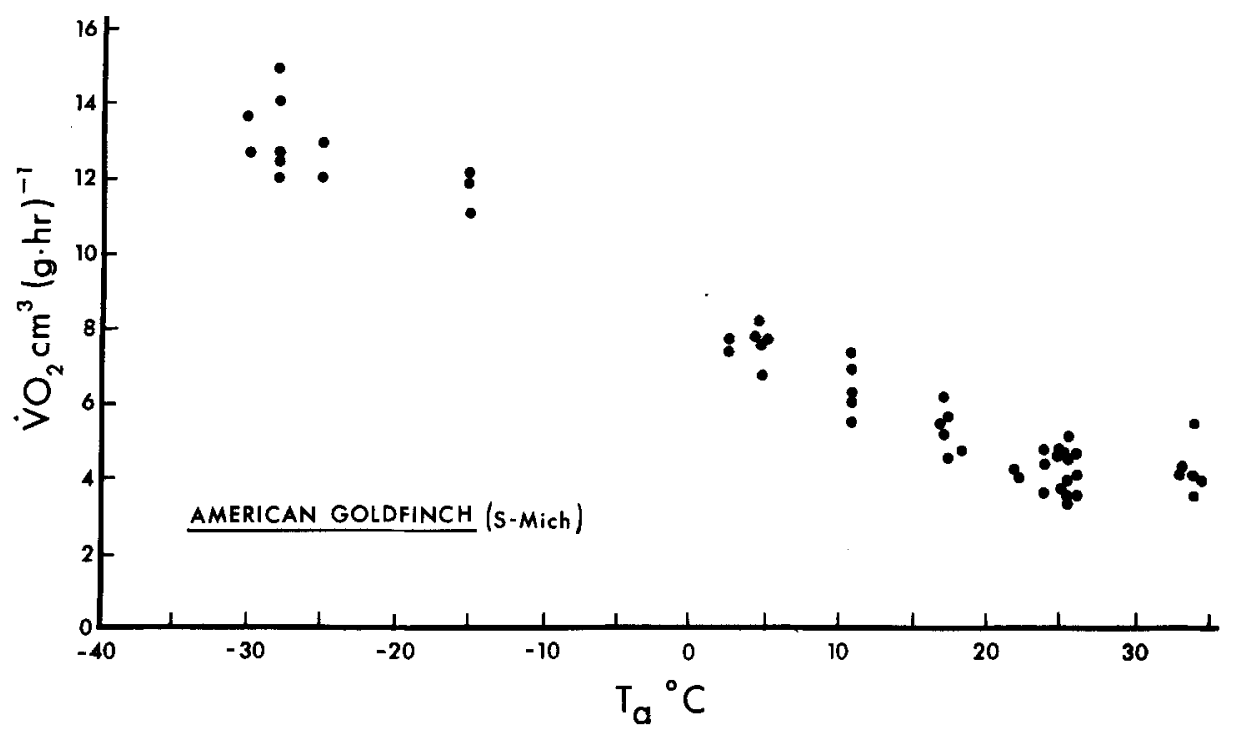

Fig. 1. Relation of metabolic rate $\left(\mathrm{V}_{\mathrm{O}_{2}}\right)$ to ambient temperature $\left(T_{\mathrm{a}}\right)$ in postabsorptive American goldfinches resting in the dark at night. Birds were captured in the summer between June and August. Each point represents the mean for one individual. An individual was measured no more than once below thermoneutrality

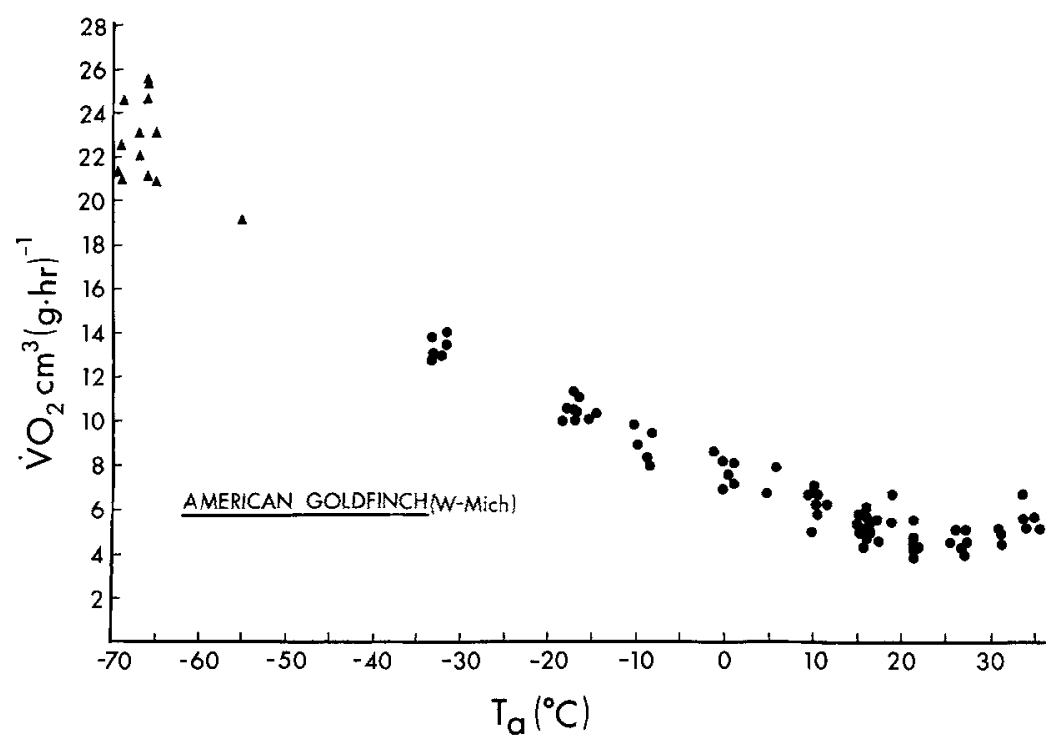

Fig. 2. Relation of metabolic rate $\left(\dot{\mathrm{V}}_{\mathrm{O}_{2}}\right)$ to ambient temperature $\left(T_{\mathrm{a}}\right)$ in postabsorptive American goldfinches resting in the dark at night. Birds were captured in the winter between December and early March. Data have been pooled for birds held in outdoor flight cages and those measured on the same day they were captured in the field. Captive individuals were measured no more than once below thermoneutrality 


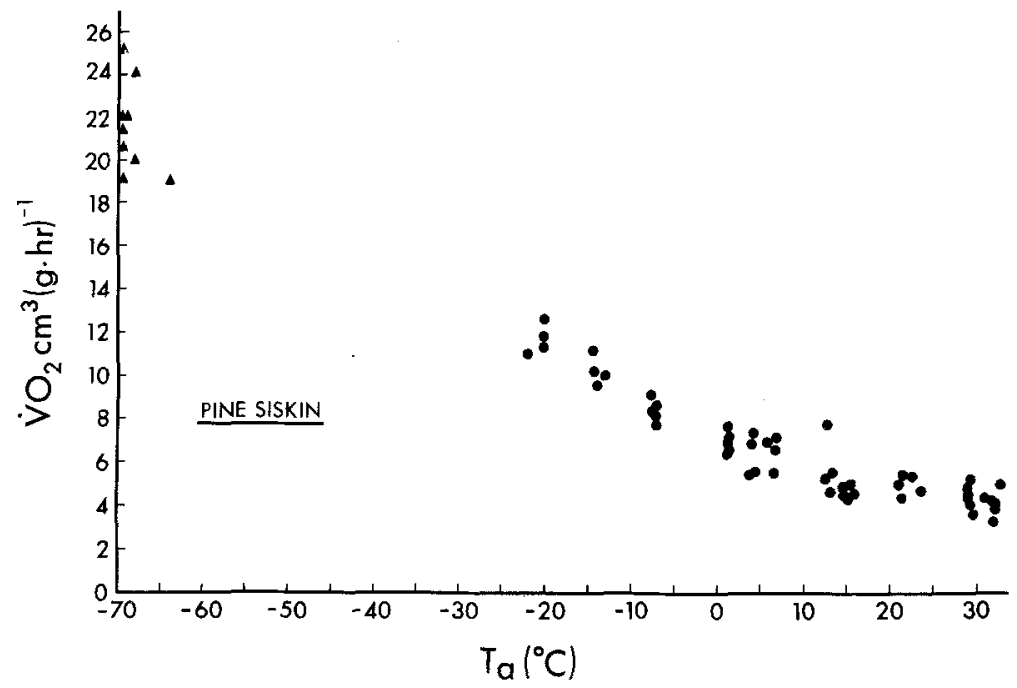

Fig. 3. Relation of metabolic rate $\left(\mathrm{V}_{\mathrm{O}_{2}}\right)$ to ambient temperature $\left(T_{\mathrm{a}}\right)$ in postabsorptive pine siskins resting in the dark at night. Birds were studied between January and early March

to zero metabolism at ambient temperatures exceeding the level of $T_{\mathrm{b}}$ by $10^{\circ} \mathrm{C}$ or more.

The regression equation best describing the relation of $\dot{\mathrm{V}}_{\mathrm{O}_{2}}$ to $T_{\mathrm{a}}$ (between $15^{\circ} \mathrm{C}$ and $-35^{\circ} \mathrm{C}$ ) for pine siskins in winter is:

$$
\begin{aligned}
& \dot{\mathrm{V}}_{\mathrm{O}_{2}}=7.46-0.19 T_{\mathrm{a}} \\
& \left(\mathrm{n}=37, \mathrm{r}=0.96, \mathrm{~S}_{\mathrm{b}}=0.01, \mathrm{~S}_{\mathrm{y} \cdot \mathrm{x}}=0.711\right)
\end{aligned}
$$

where the units are as indicated for the goldfinches. In this case, the relation between $\dot{\mathrm{V}}_{\mathrm{O}_{2}}$ and temperature does largely conform to the Newtonian model, with the regression line extrapolating to zero metabolism at $39.3^{\circ} \mathrm{C}$. The slope and the intercept of Equation (5) differ significantly from those in Equation (2) for wild goldfinches in winter $(P<0.01)$.

\section{Body Temperatures}

Body temperatures of goldfinches measured in summer at the termination of metabolic experiments conducted between $+35^{\circ} \mathrm{C}$ and $-35^{\circ} \mathrm{C}$ average $39.3 \pm 1.62(\mathrm{SD}){ }^{\circ} \mathrm{C}$. Birds of this species measured over a similar range of $T_{\mathrm{a}}$ 's in winter have a mean $T_{\mathrm{b}}$ of $39.6 \pm 1.29(\mathrm{SD}){ }^{\circ} \mathrm{C}$. The slopes of the regression lines describing the relation of $T_{\mathrm{b}}$ to $T_{\mathrm{a}}$ for both winter and summer goldfinches are slightly but significantly greater than zero $(P<0.01)$, indicating a moderate dependence of $T_{\mathrm{b}}$ on $T_{\mathrm{a}}$ for both seasons (Fig. 4). A similar dependence on $T_{\mathrm{a}}$ characterizes $T_{\mathrm{b}}$ for pine siskins. The mean $T_{\mathrm{b}}$ of pine siskins is $38.8 \pm 1.42(\mathrm{SD}){ }^{\circ} \mathrm{C}$. Goldfinches and siskins exposed to severe cold $\left(-70^{\circ} \mathrm{C}\right)$ maintain $T_{\mathrm{b}}$ 's between $34^{\circ}$ and $37^{\circ} \mathrm{C}$ until $\dot{\mathrm{V}}_{\mathrm{O}_{2}}$ decreases from peak levels (see below). When $\dot{\mathrm{V}}_{\mathrm{O}_{2}}$ drops, the birds rapidly become hypothermic within several 


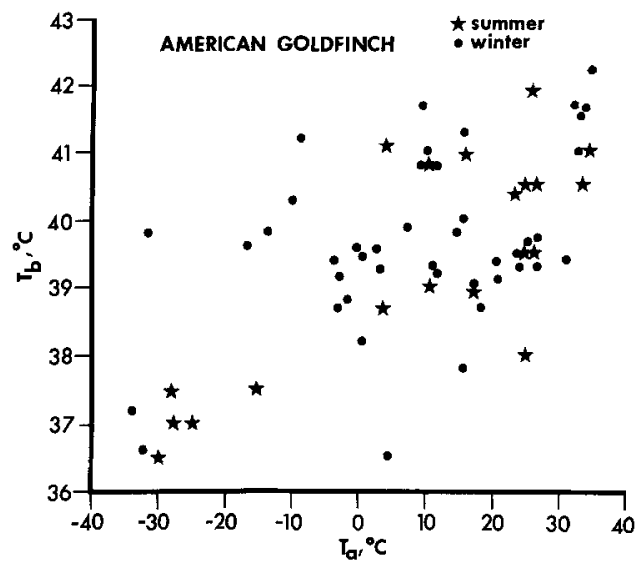

Fig. 4. The relation of body temperatures $\left(T_{\mathrm{b}}\right)$ of American goldfinches measured at the termination of metabolism experiments to ambient temperature $\left(T_{\mathrm{a}}\right)$

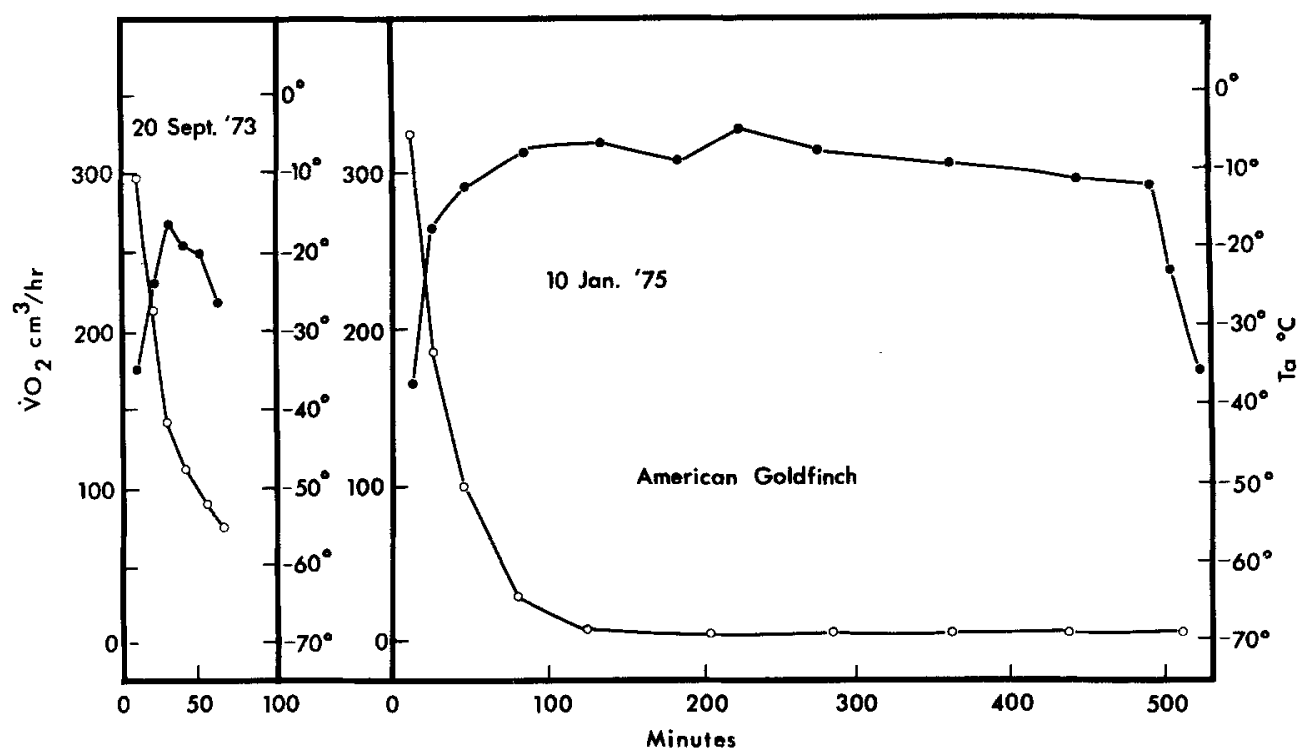

Fig. 5. Metabolic responses of individual "summer" and "winter" American goldfinches exposed to severe cold stress. Unshaded circles represent ambient temperature $\left(T_{\mathrm{a}}\right)$ and shaded circles represent oxygen consumption $\left(\dot{\mathrm{V}}_{\mathrm{O}_{2}}\right)$

minutes and $T_{\mathrm{b}}$ 's decrease to $18-29^{\circ} \mathrm{C}$. The birds able to rewarm to normal $T_{\mathrm{b}}$ 's when removed to room temperature, provided they have not cooled below $22-24^{\circ} \mathrm{C}$.

\section{Thermogenic Capacity}

Summer goldfinches during exposure to chamber temperatures steadily falling toward $-70{ }^{\circ} \mathrm{C}$ increase $\dot{\mathrm{V}}_{\mathrm{O}_{2}}$ substantially, in the manner illustrated for one bird at this season (Fig. 5). However, they maintain the elevated levels of metabo- 


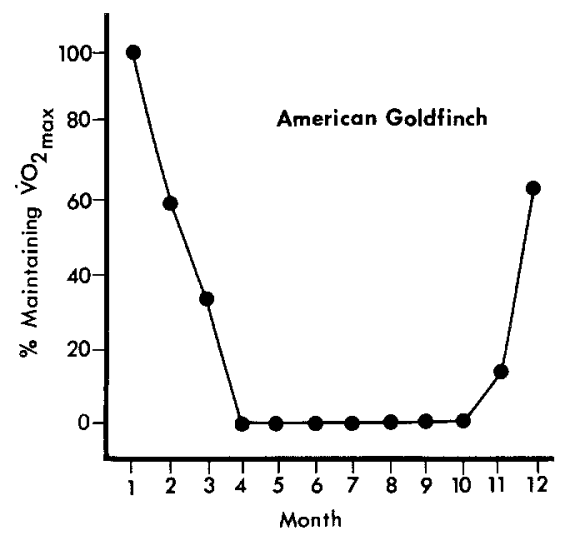

Fig. 6. Seasonal variation in metabolic responses to severe cold in American goldfinches. These data reflect the percentage of birds each month that could maintain maximal oxygen consumption necessary to remain euthermic for more than $3 \mathrm{~h}$ at $T_{\mathrm{a}}$ 's below $-60^{\circ} \mathrm{C}$. Sample sizes for the various months are as follows: Jan., 4; Feb., 5; March., 10; April, 2; May, 6; June, 2; July, 4; Aug., 4; Sept., 11; Oct., 11; Nov., 7; Dec., 8

lism for only 45-60 min and become hypothermic after that as heat production falls. In striking contrast, winter goldfinches not only increase $\dot{\mathrm{V}}_{\mathrm{O}_{2}}$ to higher levels than the summer birds, but also maintain these high levels for as much as $6-8 \mathrm{~h}$, as illustrated for one bird at this season (Fig. 5). The mean peak value for $\dot{\mathrm{V}}_{\mathrm{O}_{2}}$ of four January goldfinches with a mean post-test body mass of $12.67 \pm 0.76(\mathrm{SD}) \mathrm{g}$ is $333.3 \pm 25.1(\mathrm{SD}) \mathrm{ml} \mathrm{O}_{2} \cdot \mathrm{h}^{-1}$. Oxygen consumption of two June and four July goldfinches (mean post-test body mass of $10.14 \pm 0.65$ (SD) and $10.16 \pm 1.02$ (SD) g, respectively) shows mean peak values of $255.5 \pm 3.5$ (SD) and $251.1 \pm 32.6(\mathrm{SD}) \mathrm{ml} \mathrm{O}_{2} \cdot \mathrm{h}^{-1}$, respectively. Mean metabolic rates relative to body mass of goldfinches measured in January, $26.67 \pm 42(\mathrm{SD}) \mathrm{ml} \mathrm{O}_{2}(\mathrm{~g} \cdot \mathrm{h})^{-1}$ are not significantly different $(P=0.10)$ than those of June, $25.2 \pm 1.27$ (SD), and July, $24.7 \pm 2.94$ (SD) $\mathrm{ml} \mathrm{O}_{2}(\mathrm{~g} \cdot \mathrm{h})^{-1}$. The seasonal trend of thermogenic capacity in goldfinches is summarized in Figure 6, in which the percentages of birds maintaining elevated $\dot{\mathrm{V}}_{\mathrm{O}_{2}}$ 's for at least $3 \mathrm{~h}$ between -60 and $-70{ }^{\circ} \mathrm{C}$ in the different months are indicated. Metabolic capacity is at a peak in January in the population of goldfinches we studied, with all the birds tested maintaining thermogenesis at a sufficiently high level to remain euthermic, i.e., warmer than $34^{\circ} \mathrm{C}$, for $3 \mathrm{~h}$ or more in the severe cold. Indeed, most January birds survive much longer, but the 3 -h period is emphasized for heuristic purposes. Goldfinches do progressively less well in the ensuing months with 60,33 and $0 \%$ of the birds tested in February, March, and April maintaining increased rates of thermogenesis sufficiently to remain euthermic over the 3-h period. This capacity is absent in the birds tested from April to October. Slight improvement is apparent in November, and the performance of December birds is nearly as great as that of January individuals.

Pine siskins were utilized in $-70^{\circ} \mathrm{C}$ tests only in February and early March. Forty percent of the 5 birds tested in February and $50 \%$ of those (10 birds) in early March remain euthermic, i.e., at $T_{\mathrm{b}}$ 's exceeding $34{ }^{\circ} \mathrm{C}$, over at least 


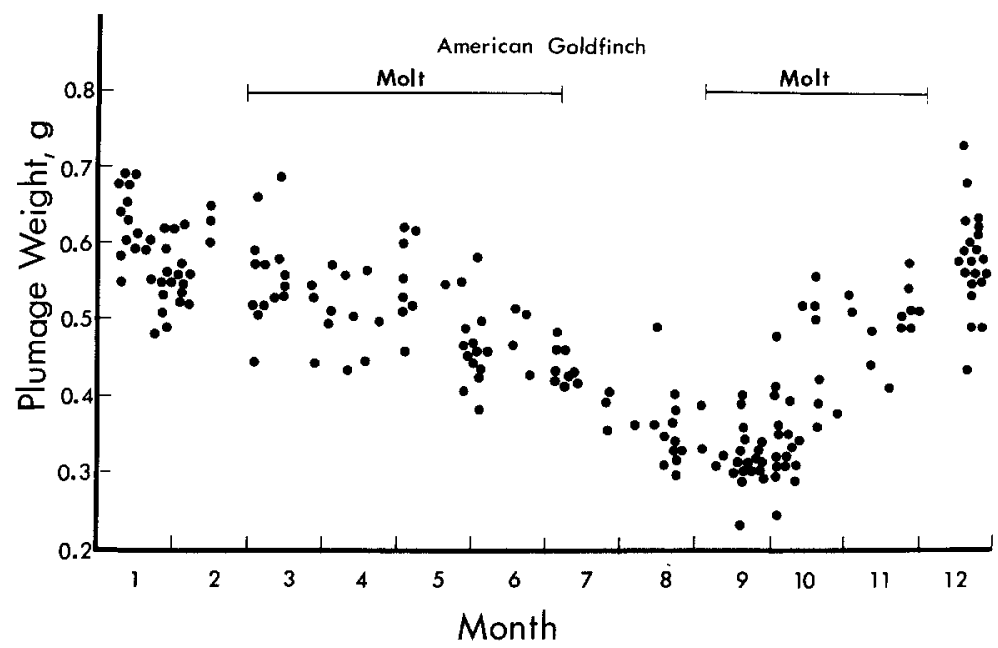

Fig. 7. Seasonal changes in dry mass of contour feathers of American goldfinches collected in the field. Each point represents a single individual. The periods of molt are outlined for the parts of the year in which any bird was captured that was molting. Goldfinches individually molted over shorter periods than shown here

$3 \mathrm{~h}$ between -60 and $-70^{\circ} \mathrm{C}$. The peak metabolic levels observed in these tests, $21.52 \pm 2.35(\mathrm{SD}) \mathrm{ml} \mathrm{O}_{2}(\mathrm{~g} \cdot \mathrm{h})^{-1}$, for siskins in February do not differ significantly from those observed in February goldfinches, $24.92 \pm 4.49$ (SD) ml $\mathrm{O}_{2}(\mathrm{~g} \cdot \mathrm{h})^{-1}$.

\section{Contour Plumage}

The dry mass of the contour feathers of goldfinches remains at a relatively high level through most of the year, including the March-May period over which the prenuptial molt occurs (Fig. 7). This suggests a close synchronization between feather loss and replacement in this molt. The contour plumage averages $0.58 \pm 0.065$ (SD) and $0.57 \pm 0.103$ (SD) g in December and January, respectively. $A$ decline in mass does occur during summer. Mean ( \pm SD values) of $0.42 \pm 0.036,0.37 \pm 0.070$, and $0.33 \pm 0.038 \mathrm{~g}$ were obtained for July, August, and September, respectively. The combined values for the two cold months were significantly $(P<0.001)$ higher than those for the three summer months. Contour plumages of 5 siskins captured in January averaged $0.63 \pm 0.085$ (SD) g, a value not differing significantly from that for goldfinches captured in the same month.

\section{Discussion}

\section{Interspecific Comparisons}

The data reported here permit us to determine how winter American goldfinches and pine siskins compare with other birds in certain thermoregulatory and 
energetic parameters important for survival in cold. After completing these comparisons, we shall approach the question of seasonal acclimatization to temperature by reviewing the information on the winter goldfinches along with data on representatives of this species at other seasons.

Foremost among the energetic parameters deserving examination are the general metabolic levels and metabolic capacities characterizing goldfinches and pine siskins in winter. Metabolic level is best treated through consideration of basal metabolic rates for the two birds. Considerable care was exercised in the determination of their BMR's. It is therefore noteworthy that the rates of the American goldfinches and pine siskins in winter exceed by approximately $50 \%$ and $40 \%$, respectively, the values calculated from the Aschoff-Pohl (1970) equation for passerine birds of comparable size during the inactive $(\rho)$ phase of their daily cycle. The actual increments of observed means over predicted values amount to more than three standard deviations in the goldfinches and two in the pine siskins. It might be argued that the relatively high rates for these birds reflect a lower degree of adjustment to test conditions than that characteristic of the animals from which the data for the Aschoff-Pohl equations were obtained; we have emphasized use of freshly captured individuals in our studies. However, we found the mean basal rate established for freshly captured goldfinches in winter to be virtually identical with that obtained for birds of this species maintained for many days in aviaries at this season. Other winter carduelines maintained in outdoor aviaries in winter and tested at night likewise have BMR's exceeding calculated values: the 16-g common redpoll (Acanthis flammea), 52\% (West, 1972); the 30-g red and white-winged crossbills (Loxia curvirostra and L. leucoptera), 19 and 7\%, respectively (Dawson and Tordoff, 1964); and the 55-g evening grosbeak (Hesperiphona vespertina), 13\% (Dawson and Tordoff, 1959). It is of interest that the three smaller representatives of this group, the American golfinch, pine siskin, and common redpoll, show the greatest relative departure from passerine norms.

The thermogenic capacities of winter goldfinches and pine siskins are impressive from the standpoints of both endurance and intensity. At $-60^{\circ} \mathrm{C}$ to $-70^{\circ} \mathrm{C}$, these diminutive birds augmented heat production sufficiently to maintain a differential of nearly $100^{\circ} \mathrm{C}$ between body core and the environment. The fact that all of the January goldfinches and half of the February pine siskins could sustain rates of heat production sufficient to maintain this differential for at least three hours is impressive. That certain of these birds could do so for $6-8 \mathrm{~h}$ or more was entirely unanticipated.

The "peak" (i.e., maximal under the conditions of our experiments) rates of metabolism attained by 4 goldfinches tested in January at -60 to $-70{ }^{\circ} \mathrm{C}$ ranged from $25.3-26.1 \mathrm{ml} \mathrm{O}_{2}(\mathrm{~g} \cdot \mathrm{h})^{-1}$, values representing 5.4- to 5.6-fold increases over BMR. Peak rates (again, the maximal ones observed under the conditions of our experiments) for 10 siskins tested in February average $21.52 \mathrm{ml}$ $\mathrm{O}_{2}(\mathrm{~g} \cdot \mathrm{h})^{-1}$. This value represents a mean increase of 4.7 -fold over BMR. The comparison of the peak values, which were measured at night, holds the risk of introducing circadian factors into the consideration of relative metabolic capacity (Pohl, 1969; Aschoff and Pohl, 1970). However, any effect of this appears slight, for the peak values tend to fall on or near the extrapolation 
of the regression line fitted to points for standard metabolic rates obtained at night below thermal neutrality (Figs. 2 and 3). This probably reflects the fact that the $T_{b}$ 's of birds thermoregulating in the severe cold during the day tended to be near levels characteristic of nighttime.

We are uncertain in the absence of tests at $T_{a}$ 's below $-70^{\circ} \mathrm{C}$ that we elicited the greatest thermogenic efforts of which sedentary goldfinches and siskins are capable. Even so, the factors by which peak metabolic rates noted in our tests involving severe cold stress exceed BMR are larger than the comparable factors obtained in studies eliciting peak as well as basal metabolic values in most other birds (see Dawson and Hudson, 1970). The factor of 5.5 characterizing the goldfinches is matched by that for the common redpoll, another cardueline (Rosenmann and Morrison, 1974). The values characterizing these carduelines are exceeded by those (12-14 times BMR) exhibited by some birds in flapping flight (Tucker, 1968, 1972; Bernstein et al., 1973). Whether or not such factors are characteristic of flying goldfinches is unknown. The equation of Pennycuick (1975) for calculating the minimal requirement for level flapping flight of a bird with the mass and wingspan of a winter goldfinch predicts minimal metabolic expenditures as low as 4.5 times BMR. Metabolic expenditure during flight is undoubtedly primarily related to the contractions of the pectoral muscles, with small contributions from the supra-coracoideus and other antagonistic muscles. The pectoral muscles comprise approximately $15-33 \%$ of body mass of small birds (Steen and Enger, 1957; Calder and King, 1974). Shivering in these muscles is probably the major source of heat produced during thermogenesis by small birds (Steen and Enger, 1957; West, 1965), for non-shivering thermogenesis is evidently not involved in the responses of adult birds to cold (see summaries by Calder and King, 1974; Richards, 1975). The peak metabolic capacity exhibited by winter goldfinches exposed to severe cold may approach minimal expenditures during flight, but certainly does not exploit the full metabolic capacities of the muscular system.

The factors of 4.7-5.5 defining metabolic expansibility of resting birds in our study are substantially exceeded by that noted for the Alaskan redbacked vole (Clethrionomys rutilus dawsoni). Rosenmann et al. (1975) report a maximal metabolic rate for this $15 \mathrm{~g}$ rodent in winter that is 8.1 times BMR. However, this larger factor reflects the fact that the BMR of this animal is only $70 \%$ those of the goldfinch and siskin, rather than any absolutely higher capacity for thermogenesis; the maximal metabolic rate for the vole is $26.4 \mathrm{ml} \mathrm{O}_{2}(\mathrm{~g} \cdot \mathrm{h})^{-1}$, a value similar to that for the goldfinches.

Information on body temperature and $\dot{V}_{\mathrm{O}_{2}}$ at various ambient temperatures permits calculation of overall coefficients for heat transfer (i.e., thermal conductances). These describe heat transfer between the body core and the environment, but are primarily determined by the plumage insulation because small birds maintain skin temperature beneath the feathers near core temperature (Dawson and Tordoff, 1959; Hissa and Palokangas, 1970; Pohl and West, 1973). It is pertinent in relation to the analysis of adjustment to cold to consider the minimal values for the heat transfer coefficients (C) in goldfinches and siskins. To insure that it is in fact such values that we are dealing with, we have 
confined our attention to results of metabolic tests in which the difference between $T_{\mathrm{b}}$ and $T_{\mathrm{a}}$ was at least $40^{\circ} \mathrm{C}$ and the actual value of $T_{\mathrm{b}}$ uncomplicated by struggling of the bird in the process of measurement at the end of the metabolic test. Data for 22 winter goldfinches and 12 winter pine siskins satisfy these specifications. The mean values of the minimal heat transfer coefficients for these birds are $0.885 \pm 0.044(\mathrm{SD})$ and $0.935 \pm 0.078(\mathrm{SD}) \mathrm{cal}\left(\mathrm{g} \cdot \mathrm{h} \cdot{ }^{\circ} \mathrm{C}\right)^{-1}$, respectively. These values differ significantly $(P<0.03)$, which is rather surprising with the lack of any significant difference in mass of the contour plumage. The relation of the minimal heat transfer coefficients for winter goldfinches and siskins indicates that the former have somewhat better overall insulation than the latter. This is manifested in the significant differences $(P<0.01)$ existing between the slopes and between the intercepts, respectively, of the regression equations describing the thermal dependence of $\dot{V}_{\mathrm{O}_{2}}$ below thermal neutrality as well as in the position of the lower critical temperature in these populations. Given the apparent lack of differences in mass of plumage between the winter goldfinches and pine siskins, it appears necessary to look to behavioral differences involving postural responses to cold in accounting for the differences in heat transfer coefficients and features of the metabolism-temperature curves. Such differences might explain why winter goldfinches depart from the so-called Newtonian model for thermal dependence of metabolism below thermal neutrality, whereas the winter siskins conform to this model, to the extent of having the regression line for $\dot{\mathrm{O}}_{\mathrm{O}_{2}}$ below thermal neutrality extrapolate to zero at an ambient temperature very close to the body temperatures observed in the metabolic tests. Conformance or departure from this model may be a rather labile feature of the responses of small birds to temperature, for West (1972) reports substantial variation in this respect among test populations of common redpolls acclimated to various combinations of temperature and photoperiod.

The minimal values of heat transfer coefficients calculated for winter goldfinches and pine siskins are within the range reported by West (1972) from his metabolic studies of common redpolls that had been acclimated or acclimatized to various combinations of photoperiod and temperature. The overall mean of the values for the redpolls, $0.819 \mathrm{cal}\left(\mathrm{g} \cdot \mathrm{h} \cdot{ }^{\circ} \mathrm{C}\right)^{-1}$ is lower than those for these other species, suggesting that this more boreal species possesses somewhat better insulation. The values for all three of these carduelines are well below the coefficient determined in March redpolls from cooling curves for dead birds (Herreid and Kessel, 1967). We concur with West's suggestion that this difference may result from differences in feather positioning, posture, and peripheral circulation between living and dead individuals.

Some perspective concerning the position of the minimal heat transfer coefficients of winter goldfinches and pine siskins relative to those of other birds of comparable size is achieved through use of the equation provided by Calder and King (1974) relating heat transfer coefficients for passerine birds to body mass. The value predicted for a bird the mass of our two carduelines (14.5 $\mathrm{g}$ in winter), $1.0736 \mathrm{cal}\left(\mathrm{g} \cdot \mathrm{h} \cdot{ }^{\circ} \mathrm{C}\right)^{-1}$, exceeds the observed values for them by approximately $10-15 \%$. Given the difference in methods of estimating the coefficients between the studies used by Calder and King to derive the equation 
and the present study, this difference seems inadequate for claiming any unusual character for the insulation of goldfinches and siskins, relative to that of other birds of comparable size.

The observed masses of dried contour plumage of summer and winter goldfinches are about $50 \%$ of the values predicted by the equation of Turcek (1966) for birds of $14.5 \mathrm{~g}$ (winter) and $12 \mathrm{~g}$ (summer) body mass. Direct comparison of our values is not completely meaningful, for Turček apparently used data for undried plumage to generate his equation and he did not specify whether he included masses of flight feathers. It is unlikely that water comprises $50 \%$ of the wet mass of plumage. Although comparison of masses of contour feathers between summer and winter birds of a single species provides a very useful index of seasonal adjustments in insulation, predictions about the quality of insulation in different species from the dry mass alone is difficult because the structure of the feathers (particularly the thickness of the shaft) may vary among them, affecting the absolute mass without modifying the resistance to heat flow.

\section{Seasonal Changes in the Insulative and Metabolic Capacities of Goldfinches}

A primary objective of this study was to determine the relative importance of metabolic and insulative changes in the acclimatization of carduelines to winter cold. It is possible to move toward such a determination with the information reported here on the American goldfinch, which was studied throughout the year.

The absence of significant changes in the BMR of American goldfinches between winter and summer places this species with others that have been studied under natural or semi-natural conditions (Irving et al., 1955; Dawson, 1958; Pohl, 1969; Hissa and Palokangas, 1970). The principal evidence for environmentally correlated shifts in mass-specific BMR of birds comes from studies of experimental acclimation to temperature. Gelineo $(1955,1964)$ provides a number of examples of such adjustments, several of which involve small cardueline finches (Acanthis cannabia, Serinus canaria, Spinus spinus, Chloris chloris, and Carduelis carduelis). The possibility that the BMR of winter goldfinches might be significantly higher than that of summer individuals of this species when the rates are expressed per unit of lean body mass will be examined in a subsequent report.

The relative stability of BMR in the goldfinches gives no indication of the striking changes over the year in the ability to remain homeothermic at $-70{ }^{\circ} \mathrm{C}$ (Fig. 6). We believe these changes reflect true shifts in metabolic capacity, for their seasonal course is quite distinct from that noted for the changes in insulation reflected by monthly values for mass of contour plumage. We noted the same thing about the goldfinches' ability to sustain elevated metabolic rates in the cold that Hart (1962) observed for evening grosbeaks: that this ability did not become fully developed with the approach of winter until well after the completion of the post-nuptial molt. We also found that this metabolic capacity began to decline in winter well before the onset of the prenuptial 
Table 1. Comparison of morphological and physiological features related to the responses of American goldfinches to cold in winter and summer

\begin{tabular}{lll}
\hline Feature & Ref. & Winter vs. Summer \\
\hline$T_{\mathrm{b}}$ at $T_{\mathrm{a}}$ 's to $-35^{\circ} \mathrm{C}$ & Fig. 4 & $\mathrm{~W} \cong \mathrm{S}$ \\
BMR & Fig. 1,2 & $\mathrm{~W} \cong \mathrm{S}$ \\
Slope of regression line for $\mathrm{V}_{\mathrm{O}_{2}}$ vs. $T_{\mathrm{a}}$ & Eq. $(1),(4)$ & $\mathrm{W} \cong \mathrm{S}$ \\
Intercept of regression line for $\mathrm{V}_{\mathrm{O}_{2}}$ vs. $T_{\mathrm{a}}$ & Eq. (1), (4) & $\mathrm{W}<\mathrm{S}$ \\
Ability to remain homeothermic at $-70^{\circ} \mathrm{C}$ & Fig. 6 & $\mathrm{~W}>\mathrm{S}$ \\
Minimal heat transfer coefficient & Text & $\mathrm{W}<\mathrm{S}$ \\
Mass of contour feathers & Fig. 7 & $\mathrm{~W}>\mathrm{S}$ \\
\hline
\end{tabular}

molt. The physiological basis of the seasonal shift in resistance to $-70{ }^{\circ} \mathrm{C}$ will be examined in subsequent reports.

A shift in insulation does occur in goldfinches between winter and summer. The intercept of the regression line fitted to the standard metabolic rates of summer goldfinches below thermoneutrality (Eq. (1)) is significantly higher than that for winter goldfinches (Eq. (4)). The slopes for these regression lines are similar, but this is not indicative of the situation with respect to the minimal heat transfer coefficients of the summer and winter birds, for neither of these populations conforms to the so-called Newtonian model. When the heat transfer coefficients are calculated individually for tests in which a differential of $40^{\circ} \mathrm{C}$ or more existed between $T_{\mathrm{b}}$ and $T_{\mathrm{a}}$, values of $0.885 \mathrm{cal}\left(\mathrm{g} \cdot \mathrm{h} \cdot{ }^{\circ} \mathrm{C}\right)^{-1}$ (see above) and $0.988 \mathrm{cal}\left(\mathrm{g} \cdot \mathrm{h} \cdot{ }^{\circ} \mathrm{C}\right)^{-1}$ are obtained for winter and summer birds respectively. These differ significantly on the basis of a non-parametric test. Thus the overall insulation of the former appears significantly greater than that of the latter. The mass of the contour feathers provides another measure of this. The mass of these feathers for January birds averages $0.574 \mathrm{~g}$. This significantly exceeds $(P<0.01)$ the respective average masses of the contour plumage of June $(0.474 \mathrm{~g})$, July $(0.425 \mathrm{~g})$, August $(0.373 \mathrm{~g})$, and September $(0.328 \mathrm{~g})$. The January birds do not differ significantly in plumage mass from birds taken in any other of the non-summer months. The seasonal differences in plumage mass appear to be correlated with the total number of feathers. Wetmore (1936) found the absolute number of contour feathers plucked from two male goldfinches in February and March to be 2,107 and 2,368 , respectively, and that from a female captured in June was 1,439.

Our observations (see Table 1) lead to a view that winter acclimatization in goldfinches is primarily a metabolic process. A difference in insulative capacity is apparent between winter and summer birds of this species. However, this is relatively minor, perhaps reflecting the constraints imposed by both small size and aerodynamic requirements. In considering the differences in insulation between winter and summer birds, it is important to note that the contour plumage is lower at the latter season primarily because of a loose coordination between feather loss and the growth of feathers in the postnuptial molt (Fig. 7). The prenuptial molt initially produces a contour plumage that is similar in mass to that covering goldfinches in the fall and winter. 
The seasonal augmentation of thermogenic capacities in goldfinches, which appears to be the principal component of acclimatization in these species, is not unprecedented. Glimpses of this metabolic type of acclimatization to winter conditions are also provided by Hart (1962) for evening grosbeaks, Barnett (1970) for house sparrows (Passer domesticus), and Lustick and Adams (1976) for starlings (Sturnus vulgaris). This form of acclimatization may involve any or all of the several possible changes in these birds: a) the establishment of increased energy reserves through winter fattening, b) the development of improved capacities for mobilizing the substrates (principally fatty acids) required in the metabolism of skeletal muscle, and c) the establishment of improved metabolic capacities in these muscles during winter. The contribution of the greater metabolic capacities of American goldfinches appears crucial to the survival of these birds, for it allows them to tolerate the combined problems of fasting overnight and inclement weather in the northern parts of their range. We shall examine the functional basis of the improved capacity in this species in a subsequent report.

Financial support for this study was provided by National Science Foundation Grants BMS 70-00858 and BMS 75-03300 to WRD. We thank Curtis Adkisson, Richard Marsh, Frances Scott, and Andrea Way for assistance in aspects of this study.

\section{References}

Aschoff, J., Pohl, H.: Rhythmic variations in energy metabolism. Fed. Proc., Fed. Amer. Soc. Exp. Biol. 29, 1541-1552 (1970)

Barnett, L.B. : Seasonal changes in temperature acclimatization of the house sparrow, Passer domesticus. Comp. Biochem. Physiol. 33, 559-578 (1970)

Bernstein, M.H., Thomas, S.P., Schmidt-Nielsen, K.: Power input during flight of the fish crow, Corvus ossifragus. J. exp. Biol. 58, 401-410 (1973)

Calder, W.A., King, J.R.: Thermal and caloric relations of birds. In: Avian biology, Vol. 4 (eds. D.S. Farner, J.R. King,), pp. 259-413. New York: Academic Press 1974

Chaffee, R.R.J., Mayhew, W.W., Drebin, M., Cassuto, Y.: Studies on thermogenesis in coldacclimated birds. Canad. J. Biochem. Physiol. 41, 2215-2220 (1963)

Chaplin, S.B.: Daily energetics of the black-capped chickadee, Parus atricapillus, in winter. J. comp. Physiol. 89, 321-330 (1974)

Dawson, W.R.: Relation of oxygen consumption and evaporative water loss temperature in the cardinal. Physiol. Zool. 31, 37-48 (1958)

Dawson, W.R., Fisher, C.D.: Responses to temperature by the spotted nightjar (Eurostopodus guttatus). Condor 71, 49-53 (1969)

Dawson, W.R., Hudson, J.W.: Birds. In: Comparative physiology of thermoregulation, Vol. 1 (ed. G.C. Whittow), pp. 223-310. New York: Academic Press 1970

Dawson, W.R., Tordoff, H.B.: Relation of oxygen consumption to temperature in the evening grosbeak. Condor 61, 388-396 (1959)

Dawson, W.R., Tordoff, H.B.: Relation of oxygen consumption to temperature in the red and white-winged crossbills. Auk 81, 26-35 (1964)

Depocas, F.J., Hart, J.S. : Use of the Pauling oxygen analyzer for measurement of oxygen consumption in open circuit systems and short-lag, closed circuit apparatus. J. appl. Physiol. 10, 388-392 (1957)

Drent, R.H., Stonehouse, B.: Thermoregulatory responses of the Peruvian penguin, Spheniscus humboldti. Comp. Biochem. Physiol. 40 A, 689-710 (1971)

Evans, P.R.: Winter fat deposition and overnight survival of yellow buntings (Emberiza citrinella L.). J. anim. Ecol. 38, 415-423 (1969) 
Gelineo, S.: Temperature d'adaptation et production de chaleur chez les oiseaux de petite taille. Arch. Sci. Physiol. 9, 225-243 (1955)

Gelineo, S.: Organ systems in adaptation: the temperature regulating system. In: Handbook of physiology, Sect. 4 (ed. D.B. Dill), pp. 259-282. Washington, D.C.: Amer. Physiol. Soc. 1964

Hart, J.S.: Seasonal acclimatization in four species of small wild birds. Physiol. Zool. 35, 224-236 (1962)

Herreid, C.F., Kessel, B.: Thermal conductance in birds and mammals. Comp. Biochem. Physiol. 21, 405-414 (1967)

Hissa, R., Palokangas, R.: Thermoregulation in the titmouse (Parus major L.). Comp. Biochem. Physiol. 33, 941-953 (1970)

Irving, L., Krog, H., Monson, M.: The metabolism of some Alaskan animals in winter and summer. Physiol. Zool. 28, 173-185 (1955)

King, J.R., Farner, D.S.: The adaptive role of winter fattening in the white-crowned sparrow with comments on its regulation. Amer. Nat. 100, 403-418 (1966)

Lindley, D.V.: Introduction to probability and statistics. London: Cambridge 1965

Lustick, S., Adams, J.: Seasonal variation in the effects of wetting on the energetics and survival of starlings (Sturnus vulgaris). Physiol. Zool., in press (1976)

Newton, I.: Winter fattening in the bullfinch. Physiol. Zool. 42, 96-107 (1969)

Palokangas, R., Nuuja, R., Koivusaari, J.: Seasonal changes in some thermoregulatory variables of the house sparrow (Passer domesticus L.). Comp. Biochem. Physiol. 52 A, 299-304 (1975)

Pennycuick, C.J.: Mechanics of flight. In: Avian biology, Vol. 5, (eds. D.S. Farner, J.R. King), pp. 1-75. New York: Academic Press 1975

Pohl, H.: Some factors influencing the metabolic response to cold in birds. Fed. Proc., Fed. Amer. Soc. Exp. Biol. 28, 1059-1064 (1969)

Pohl, H., West, G.C.: Daily and seasonal variation in metabolic response to cold during rest and forced excercise in the common redpoll. Comp. Biochem. Physiol. 45A, 851-867 (1973)

Richards, S.A.: Thermal homeostasis in birds. Symp. Zool. Soc. Lond. 35, 65-96 (1975)

Rosenmann, M., Morrison, P.R.: Maximum oxygen consumption and heat loss facilitation in small homeotherms by He- $\mathrm{O}_{2}$. Amer. J. Physiol. 226, 490-495 (1974)

Rosenmann, M., Morrison, P., Feist, D. : Seasonal changes in the metabolic capacity of red-backed voles. Physiol. Zool. 48, 303-310 (1975)

Steen, J.: Climatic adaptation in some small northern birds. Ecology 39, 625-629 (1958)

Steen, J., Enger, P.S.: Muscular heat production in pigeons during exposure to cold. Amer. J. Physiol. 191, 157-158 (1957)

Tucker, V.A.: Respiratory exchange and evaporative water loss in the flying budgerigar. J. exp. Biol. 48, 67-87 (1968)

Tucker, V.A.: Metabolism during flight in the laughing gull, Larus atricilla. Amer. J. Physiol. 222, 237-245 (1972)

Turček, F.J.: On plumage quantity in birds. Ekol. Pol., Ser. A 14, 617-633 (1966)

Veghte, J.H.: Thermal and metabolic responses of the grey jay to cold stress. Physiol. Zool. 37, 316-328 (1964)

West, G.C.: Responses and adaptations of wild birds to environmental temperature. In: Comparative physiology of temperature regulation, Part 3, (eds. J.P. Hannon, E.G. Viereck), pp. 291-333. Fort Wainwright, Alaska: Arctic Aeromed. Lab. 1962

West, G.C.: Shivering and heat production in wild birds. Physiol. Zool. 38, 111-120 (1965)

West, G.C.: The effect of acclimation and acclimatization on the resting metabolic rate of the common redpoll. Comp. Biochem. Physiol. 43A, 293-310 (1972)

West, G.C., Hart, J.S. : Metabolic responses of evening grosbeaks to constant and to fluctuating temperatures. Physiol. Zool. 39, 171-184 (1966)

Wetmore, A.: The number of contour feathers in passeriform and related birds. Auk 53, 159-169 (1936)

Wetmore, A., Friedmann, H., Amadon, .D., Lincoln, F.C., Lowery, G.H., Jr., Miller, A.H., Peters, J.L., Pitelka, F.A., van Rossem, A.J., van Tyne, S., and Zimmer, J.T.: Checklist of North American birds, 5th ed. Baltimore: American Ornithologists' Union 1957 